Western University

Scholarship@Western

Chemistry Publications

Chemistry Department

Fall 9-18-2017

\title{
Boron Difluoride Adducts of a Flexidentate Pyridine-Substituted Formazanate Ligand: Property Modulation via Protonation and Coordination Chemistry
}

Stephanie M. Barbon

Jasmine V. Buddingh

Ryan R. Maar

Joe Gilroy

jgilroy5@uwo.ca

Follow this and additional works at: https://ir.lib.uwo.ca/chempub

Part of the Chemistry Commons

Citation of this paper:

Barbon, Stephanie M.; Buddingh, Jasmine V.; Maar, Ryan R.; and Gilroy, Joe, "Boron Difluoride Adducts of a Flexidentate PyridineSubstituted Formazanate Ligand: Property Modulation via Protonation and Coordination Chemistry" (2017). Chemistry Publications. 80 .

https://ir.lib.uwo.ca/chempub/80 


\title{
Boron Difluoride Adducts of a Flexidentate Pyridine-Substituted
}

\section{Formazanate Ligand: Property Modulation via Protonation and Coordination Chemistry}

Stephanie M. Barbon, Jasmine V. Buddingh, Ryan R. Maar, Joe B. Gilroy*

\author{
Department of Chemistry and the Centre for Advanced Materials and Biomaterials Research \\ (CAMBR), The University of Western Ontario, 1151 Richmond St. N., London, Ontario, \\ Canada, N6A 5B7. Telephone: +1-519-661-2111 ext. 81561, E-mail: joe.gilroy@uwo.ca
}




\begin{abstract}
The synthesis and characterization of a flexidentate pyridine-substituted formazanate ligand and its boron difluoride adducts, formed via two different coordination modes of the title ligand, are described. The first adduct adopted a structure that was typical of other boron difluoride adducts of triarylformazanate ligands and contained a free pyridine subsituent, while the second was formed via chelation of nitrogen atoms from the formazanate backbone and the pyridine substituent. Stepwise protonation of the pydridine-functionalized adduct, which is essentially non-emissive, resulted in a significant increase in the fluorescence quantum yield up to a maximum of $18 \%$, prompting study of this adduct as a $\mathrm{pH}$ sensor. The coordination chemistry of each adduct was explored through reactions with nickel(II) bromide $\left[\mathrm{NiBr}_{2}\left(\mathrm{CH}_{3} \mathrm{CN}\right)_{2}\right]$, triflate $\left[\mathrm{Ni}(\mathrm{OTf})_{2}\right]$ and 1,1,1,4,4,4-hexafluoroacetylacetonate $\left[\mathrm{Ni}(\mathrm{hfac})_{2}\left(\mathrm{H}_{2} \mathrm{O}\right)_{2}\right]$ salts. Coordination to nickel(II) ions altered the physical properties of the boron difluoride formazanate adducts, including red-shifted absorption maxima and less negative reduction potentials. Together, these studies have demonstrated that the physical and electronic properties of boron difluoride adducts of formazanate ligands can be readily modulated through protonation and coordination chemistry.
\end{abstract}

\title{
Introduction
}

Boron adducts of $\mathrm{N}$-donor ligands are of significant interest as a result of their use in a variety of applications. ${ }^{1-3}$ Common examples, including BODIPYs, ${ }^{2} a z a-B O D I P Y s{ }^{4}$ and BOPHYs,${ }^{5}$ have been used in photovoltaics ${ }^{6,7}$ and batteries, ${ }^{8}$ for cell imaging ${ }^{9,10}$ and photodynamic therapy, ${ }^{1}$ and as electrochemiluminescence (ECL) emitters. ${ }^{11,12}$ Sensing with boron adducts of $N$-donor ligands is another widely explored area, ${ }^{13-17}$ though their use in $\mathrm{pH}$ sensing remains relatively 
understudied. ${ }^{18}$ Accurate $\mathrm{pH}$ measurements are essential in environmental studies and biological applications, especially considering maintaining a normal intracellular $\mathrm{pH}$ is necessary for the regulation of critical processes such as ion transport and apoptosis. ${ }^{19,20}$ BODIPYs and azaBODIPYs have been studied as $\mathrm{pH}$ sensors, some of which are operative over wide $\mathrm{pH}$ ranges. ${ }^{21}$ Others dually sense the presence of ions or oxygen and $\mathrm{pH},{ }^{22,23}$ emit in the near- $\mathrm{IR}^{24}$ and/or have demonstrated cell permeability and low toxicity. ${ }^{25}$

The redox-activity and emissive nature of many boron adducts of $N$-donor ligands also makes them attractive targets for incorporation into complexes with transition metals. Generally, the combination of an emissive boron adduct with a transition metal results in decreased or quenched emission. However, Wang and others have demonstrated that platinum complexes (e.g., 1) of boron-containing ligands have high phosphorescence quantum yields. ${ }^{26-29}$ The complexation of transition metals by these boron adducts also often results in an increase in the complexity of the oxidation and/or reduction processes, as is the case with $\mathrm{Ru}(\mathrm{bpy})_{2}$ complexes of BODIPYs (e.g., 2) and other metal complexes..$^{30-32}$ The Hicks group has studied palladium(II) complexes of 'Nindigo' ligands, which also contains a $\mathrm{BF}_{2}$ adduct (e.g., 3). They demonstrate that the absorption properties and reduction potential of the $\mathrm{BF}_{2}$ adduct can be tuned via the coordinated metal. ${ }^{33}$ The Hong group has also taken advantage of the ECL of the BODIPY unit to devise BODIPY-zinc(II) complexes (e.g., 4) which act as sensors for phosphates. In the absence of phosphates, the BODIPY-zinc(II) complex is ECL active. However, when phosphates bind to the complex, ECL is quenched. ${ }^{34}$ 

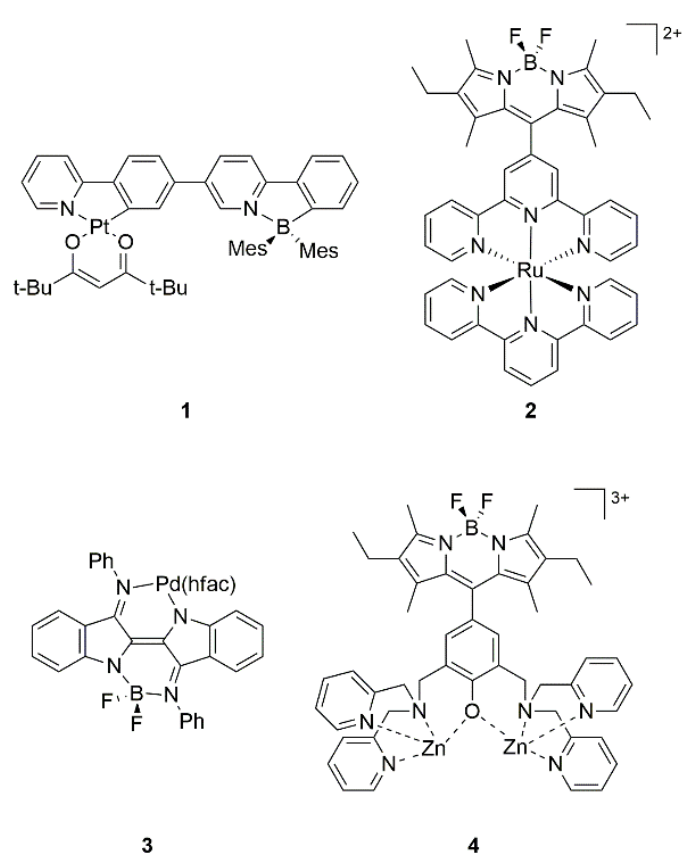

One way to expand the range of properties associated with boron adducts of $N$-donor ligands is by the incorporation of additional heteroatoms into ligand backbones toward the realization of multiple coordination modes for a single ligand (i.e., flexidentate ligand behavior). For example, the Svobodová group has synthesized flexidentate cyclic enaminone ligands that form diphenyl boron adducts $\mathbf{5 a}$ and $\mathbf{5 b}$. They observed irreversible conversion of $\mathbf{5 a}$ into $\mathbf{5 b}$ at elevated temperature. Similarly, the Aprahamian group has developed a flexidentate hydrazone ligand, ${ }^{35}$ which formed $\mathrm{BF}_{2}$ adducts $\mathbf{6 a}$ and $\mathbf{6 b}$ under typical conditions for the installation of ' $\mathrm{BF}_{2}$ ' groups. ${ }^{36}$ The authors used $\mathbf{6 b}$, which exhibits visible light cis-trans isomerization, for a variety of applications including the measurement of solution viscosity ${ }^{15}$ and detection of acids and bases. $^{13}$

Our group is interested in the chemistry of formazanate ligands and their boron adducts. We, and others, have previously shown that these compounds are fluorescent and have interesting electronic properties, which are tunable through substituent variation. ${ }^{37-41}$ Their utility as 
fluorescence cell-imaging agents, ${ }^{42,43}$ ECL emitters, ${ }^{44}$ precursors to unusual BN heterocycles,,${ }^{45,46}$ aggregation-induced emission (AIE) luminogens, ${ }^{47}$ and building blocks in polymeric materials has also been explored in detail. ${ }^{48,49}$ Herein, we demonstrate the synthesis of a pyridinesubstituted formazanate ligand, its $\mathrm{BF}_{2}$ adducts, and the modulation of adduct properties via protonation and coordination chemistry.

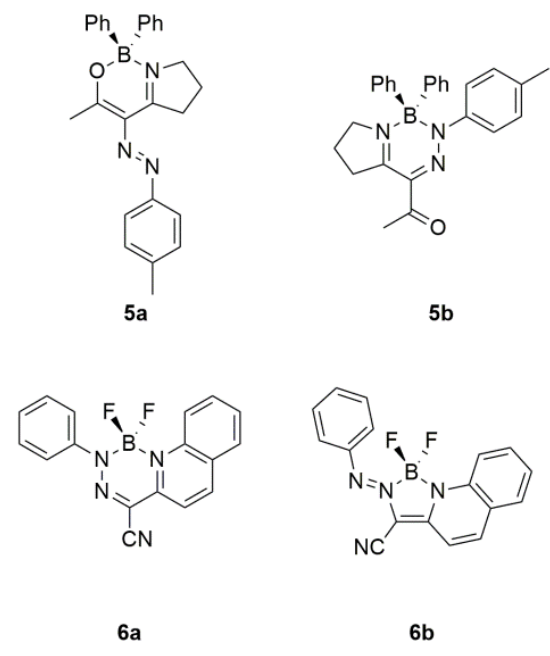

\section{Experimental section}

\section{General considerations}

Reactions and manipulations were carried out under a nitrogen atmosphere using standard Schlenk techniques unless otherwise stated. Solvents were obtained from Caledon Laboratories, dried using an Innovative Technologies Inc. solvent purification system, collected under vacuum and stored under a nitrogen atmosphere over $4 \AA$ molecular sieves. Reagents were purchased from Sigma-Aldrich or Alfa Aesar and used as received. NMR spectra were recorded on 400 MHz $\left({ }^{1} \mathrm{H}: 399.8 \mathrm{MHz},{ }^{11} \mathrm{~B}: 128.3 \mathrm{MHz},{ }^{19} \mathrm{~F}: 376.1 \mathrm{MHz}\right)$ or $600 \mathrm{MHz}\left({ }^{1} \mathrm{H}: 599.5 \mathrm{MHz},{ }^{13} \mathrm{C}\right.$ : 150.8 MHz) Varian INOVA instruments. ${ }^{1} \mathrm{H}$ NMR spectra were referenced to residual $\mathrm{CHCl}_{3}$ (7.26 ppm) and ${ }^{13} \mathrm{C}$ NMR spectra were referenced to $\mathrm{CDCl}_{3}(77.2 \mathrm{ppm}) .{ }^{11} \mathrm{~B}$ spectra were 
referenced to $\mathrm{BF}_{3} \cdot \mathrm{OEt}_{2}$ at $0 \mathrm{ppm}$ and ${ }^{19} \mathrm{~F}$ spectra were referenced to $\mathrm{CFCl}_{3}$ at $0 \mathrm{ppm}$. Mass spectrometry data were recorded in positive-ion mode using a high-resolution Finnigan MAT 8400 spectrometer using electron impact ionization or a Micromass LCT electrospray time-offlight mass spectrometer. UV-vis absorption spectra were recorded using a Cary 5000 instrument. Four separate concentrations were run for each sample and molar extinction coefficients were determined from the slope of a plot of absorbance against concentration. FT-IR spectra were recorded using an attenuated total reflectance (ATR) attachment using a Bruker Vector 33 FT-IR spectrometer. Emission spectra were obtained using a Photon Technology International QM-4 SE spectrofluorometer. Excitation wavelengths were chosen based on $\lambda_{\max }$ from the respective UV-vis absorption spectrum in the same solvent. Fluorescence quantum yields were estimated relative to $\left[\mathrm{Ru}(\mathrm{bpy})_{3}\right]\left[\mathrm{PF}_{6}\right]_{2}$ and corrected for wavelength dependent detector sensitivity (Figure S1). ${ }^{50,51}$

\section{Electrochemical methods}

Cyclic voltammetry experiments were performed with a Bioanalytical Systems Inc. (BASi) Epsilon potentiostat and analyzed using BASi Epsilon software. Electrochemical cells consisted of a three-electrode setup including a glassy carbon working electrode, platinum wire counter electrode and silver wire pseudo reference electrode. Experiments were run at scan rates of 100 $\mathrm{mV} \mathrm{s}^{-1}$ in degassed $\mathrm{CH}_{2} \mathrm{Cl}_{2}$ solutions of the analyte $(\sim 1 \mathrm{mM})$ and supporting electrolyte $(0.1 \mathrm{M}$ $\left.\left[n \mathrm{Bu}_{4} \mathrm{~N}\right]\left[\mathrm{PF}_{6}\right]\right)$. Cyclic voltammograms were referenced against an internal standard $(\sim 1 \mathrm{mM}$ ferrocene) and corrected for internal cell resistance using the BASi Epsilon software.

\section{X-ray crystallography details}

The samples were mounted on a MiTeGen polyimide micromount with a small amount of Paratone $N$ oil. X-ray measurements were made on a Bruker Kappa Axis Apex2 diffractometer 
$\left(\mathbf{8 a}, \mathbf{8} \mathbf{a} \cdot \mathbf{H}^{+}\right)$or Nonius KappaCCD Apex2 diffractometer $(\mathbf{8 b}, \mathbf{9 a}, \mathbf{1 0 a}, \mathbf{1 0 b})$ at a temperature of $110 \mathrm{~K}$. Initial indexing indicated that the sample crystal for 10a was non-merohedrally twinned. The twin law of the first fraction was determined to be:

$\begin{array}{rrr}-1.000 & 0.000 & 0.000 \\ 0.000 & -1.000 & 0.001 \\ -0.496 & 0.090 & 1.000\end{array}$

which represents a $180.0^{\circ}$ rotation about [001]. The twin law of the second fraction was determined to be:

$\begin{array}{rrr}0.940 & 0.164 & 0.000 \\ -0.171 & 1.033 & -0.002 \\ -0.009 & 0.043 & 1.000\end{array}$

which represents a $9.3^{\circ}$ rotation about [001]. The twin law was included in the refinement as an adjustable parameter (vide infra).

The data collection strategy included a number of $\omega$ and $\varphi$ scans which collected data over a range of angles, $2 \theta$. The frame integration was performed using SAINT. ${ }^{52}$ The resulting raw data was scaled and absorption corrected using a multi-scan averaging of symmetry equivalent data using SADABS $\left(\mathbf{8 a}, \mathbf{8} \mathbf{a} \cdot \mathbf{H}^{+}, \mathbf{8 b}, \mathbf{9 a}, \mathbf{1 0 b}\right)^{53}$ or TWINABS $(\mathbf{1 0 a}){ }^{54}$ The structure was solved by using a dual space methodology using the SHELXT program. ${ }^{55}$ All non-hydrogen atoms were obtained from the initial solution. Hydrogen atoms were introduced at idealized positions and were allowed to refine isotropically $(\mathbf{8 a}, \mathbf{8 b})$, allowed to ride on the parent atom $(\mathbf{1 0 a}, \mathbf{1 0 b})$, or a combination of the two methods were used $\left(\mathbf{8 a} \cdot \mathbf{H}^{+}, \mathbf{9 a}\right)$. The twin fractions of $\mathbf{1 0 a}$ refined to values of 0.3337 and 0.1632 . The structural model was fit to the data using full matrix leastsquares based on $F^{2}$. The difference map of $9 \mathbf{a}$ and $10 \mathbf{a}$ showed regions of electron density that could not be accurately modeled accurately. Thus the PLATON SQUEEZE calculated structure 
factors including corrections for anomalous dispersion program ${ }^{56}$ were used and analysis was continued on this data. All structures were refined using the SHELXL-2014 program from the SHELXT suite of crystallographic software. ${ }^{55}$ See Table S1 and CCDC $1555851-1555856$ for additional crystallographic data.

\section{Formazan 7}

In air, $p$-tolylhydrazine hydrochloride $(1.31 \mathrm{~g}, 8.26 \mathrm{mmol})$ was dissolved in EtOH $(10 \mathrm{~mL})$ with $\mathrm{NEt}_{3}(1.52 \mathrm{~g}, 2.10 \mathrm{~mL}, 15.0 \mathrm{mmol})$ before 2-pyridine carboxaldehyde $(0.90 \mathrm{~g}, 0.80 \mathrm{~mL}, 9.4$ mmol) was added and the solution stirred for $10 \mathrm{~min}$. After this time, a light yellow precipitate had formed and $\mathrm{CH}_{2} \mathrm{Cl}_{2}(75 \mathrm{~mL})$ and deionized $\mathrm{H}_{2} \mathrm{O}(75 \mathrm{~mL})$ were added to form a biphasic reaction mixture. $\mathrm{Na}_{2} \mathrm{CO}_{3}(2.98 \mathrm{~g}, 28.1 \mathrm{mmol})$ and $n \mathrm{Bu}_{4} \mathrm{NBr}(0.27 \mathrm{~g}, 0.84 \mathrm{mmol})$ were added, and the mixture was cooled with stirring for $30 \mathrm{~min}$ in an ice bath to $0{ }^{\circ} \mathrm{C}$. In a separate flask, $p$ toluidine $(0.90 \mathrm{~g}, 8.4 \mathrm{mmol})$ and concentrated $\mathrm{HCl}(2.1 \mathrm{~mL}, 25 \mathrm{mmol})$ were mixed in deionized $\mathrm{H}_{2} \mathrm{O}(15 \mathrm{~mL})$ and cooled in an ice bath. A cooled solution of sodium nitrite $(0.66 \mathrm{~g}, 9.6 \mathrm{mmol})$ in deionized $\mathrm{H}_{2} \mathrm{O}(5 \mathrm{~mL})$ was added slowly to the amine solution over a 5 min period. This mixture was then stirred at $0{ }^{\circ} \mathrm{C}$ for $30 \mathrm{~min}$, after which time it was added dropwise to the biphasic reaction mixture described above over a 10 min period. The resulting solution was stirred for 18 h, gradually turning dark red over this time. The dark red organic fraction was then washed with deionized $\mathrm{H}_{2} \mathrm{O}(3 \times 50 \mathrm{~mL})$, dried over $\mathrm{MgSO}_{4}$, gravity filtered and concentrated in vacuo. The resulting residue was purified by flash chromatography $\left(7: 2: 1\right.$ hexanes: $\mathrm{CH}_{2} \mathrm{Cl}_{2}: \mathrm{EtOAc}$, silica gel) to afford a dark red microcrystalline solid. Yield $=0.88 \mathrm{~g}, 32 \%$. M.p $132-135{ }^{\circ} \mathrm{C} .{ }^{1} \mathrm{H}$ NMR $\left(400.1 \mathrm{MHz}, \mathrm{CDCl}_{3}\right): \delta 16.07(\mathrm{~s}, 1 \mathrm{H}, \mathrm{NH}), 9.08\left(\mathrm{~d},{ }^{3} J_{\mathrm{HH}}=6 \mathrm{~Hz}, 1 \mathrm{H}, \operatorname{aryl~CH}\right), 8.36\left(\mathrm{~d},{ }^{3} J_{\mathrm{HH}}=8\right.$

$\mathrm{Hz}, 1 \mathrm{H}$, aryl $\mathrm{CH}), 8.27-8.25(\mathrm{~m}, 1 \mathrm{H}$, aryl $\mathrm{CH}), 7.77\left(\mathrm{~d},{ }^{3} J_{\mathrm{HH}}=8 \mathrm{~Hz}, 4 \mathrm{H}\right.$, aryl $\left.\mathrm{CH}\right), 7.56-7.54$ $(\mathrm{m}, 1 \mathrm{H}, \operatorname{aryl} \mathrm{CH}), 7.21\left(\mathrm{~d},{ }^{3} J_{\mathrm{HH}}=8 \mathrm{~Hz}, 4 \mathrm{H}\right.$, aryl $\left.\mathrm{CH}\right), 2.33\left(\mathrm{~s}, 6 \mathrm{H}, \mathrm{CH}_{3}\right) \cdot{ }^{13} \mathrm{C}\left\{{ }^{1} \mathrm{H}\right\}$ NMR $(150.7$ 
$\left.\mathrm{MHz}, \mathrm{CDCl}_{3}\right): \delta 148.7,144.7,144.2,142.4,140.5,133.0,130.5,122.8,122.4,120.4,21.6 . \mathrm{FT}-$ IR(ATR): 3032 (m), 2918 (m), 2857 (w), 1599 (m), 1582 (m), 1564 (m), 1511 (m), 1465 (s), $1428(\mathrm{~m}), 1349$ (m), 1263 (s), 1235 (s), 1105 (s), 808 (s), $788(\mathrm{~m}) \mathrm{cm}^{-1}$. UV-Vis $\left(\mathrm{CH}_{2} \mathrm{Cl}_{2}\right): \lambda_{\max }$ $474 \mathrm{~nm}\left(\varepsilon=19,100 \mathrm{M}^{-1} \mathrm{~cm}^{-1}\right)$. Mass Spec. (EI, +ve mode): exact mass calculated for $\left[\mathrm{C}_{20} \mathrm{H}_{19} \mathrm{~N}_{5}\right]^{+}:$329.1640; exact mass found: 329.1639; difference: $-0.3 \mathrm{ppm}$.

\section{Adducts 8a and 8b}

Formazan 7 (1.92 g, $5.83 \mathrm{mmol})$ was dissolved in dry toluene $(200 \mathrm{~mL}) . \mathrm{NEt}_{3}(1.77 \mathrm{~g}, 2.44 \mathrm{~mL}$, $17.5 \mathrm{mmol}$ ) was then added slowly and the solution was stirred for $10 \mathrm{~min}$ before $\mathrm{BF}_{3} \cdot \mathrm{OEt}_{2}(4.11$ g, $3.57 \mathrm{~mL}, 29.0 \mathrm{mmol}$ ) was added and the solution was heated with stirring at $80^{\circ} \mathrm{C}$ for $18 \mathrm{~h}$. The solution gradually turned from dark red to dark purple during this time. After cooling to 22 ${ }^{\circ} \mathrm{C}$, deionized $\mathrm{H}_{2} \mathrm{O}(10 \mathrm{~mL})$ was added to quench any excess reactive boron-containing compounds. The purple toluene solution was then washed with deionized $\mathrm{H}_{2} \mathrm{O}(3 \times 50 \mathrm{~mL})$, dried over $\mathrm{MgSO}_{4}$, gravity filtered and concentrated in vacuo. The resulting residue was purified by flash chromatography $\left(\mathrm{CH}_{2} \mathrm{Cl}_{2}\right.$, silica gel) to afford $\mathbf{8 a}\left(R_{f}\right.$ : $\left.=0.35\right)$ as a dark red microcrystalline solid and $\mathbf{8 b}\left(R_{f}:=0.88\right)$ as an orange microcrystalline solid after removal of the solvent in vacuo.

\section{$8 \mathbf{a}$}

Yield $=0.69$ g, 31\%. M.p $162-164{ }^{\circ} \mathrm{C} .{ }^{1} \mathrm{H}$ NMR $\left(400.1 \mathrm{MHz}, \mathrm{CDCl}_{3}\right): \delta 8.77-8.76(\mathrm{~m}, 1 \mathrm{H}$, aryl $\mathrm{CH}), 8.15-8.14(\mathrm{~m}, 1 \mathrm{H}$, aryl $\mathrm{CH}), 7.83-7.80(\mathrm{~m}, 5 \mathrm{H}$, aryl $\mathrm{CH}), 7.35-7.33(\mathrm{~m}, 1 \mathrm{H}$, aryl $\mathrm{CH}), 7.26$ $\left(\mathrm{d},{ }^{3} \mathrm{~J}_{\mathrm{HH}}=8 \mathrm{~Hz}, 4 \mathrm{H}\right.$, aryl $\left.\mathrm{CH}\right), 2.41\left(\mathrm{~s}, 6 \mathrm{H}, \mathrm{CH}_{3}\right) .{ }^{13} \mathrm{C}\left\{{ }^{1} \mathrm{H}\right\} \mathrm{NMR}\left(150.7 \mathrm{MHz}, \mathrm{CDCl}_{3}\right): \delta$ 152.0, 150.0, 141.7, 140.5, 136.8, 129.8, 129.7, 123.6, 121.0, 110.1, 21.4. ${ }^{11} \mathrm{~B}$ NMR (128.3 MHz, $\left.\mathrm{CDCl}_{3}\right): \delta-0.6\left(\mathrm{t},{ }^{1} J_{\mathrm{BF}}=28 \mathrm{~Hz}\right) .{ }^{19} \mathrm{~F}$ NMR $\left(376.1 \mathrm{MHz}, \mathrm{CDCl}_{3}\right): \delta-144.8\left(\mathrm{q},{ }^{1} J_{\mathrm{FB}}=28 \mathrm{~Hz}\right) . \mathrm{FT}-$ 
IR(ATR): 3014 (m), 2916 (m), 1604 (m), 1584 (m), 1379 (m), 1352 (m), 1316 (s), 1299 (s), 1178 (m), 1109 (s), $1021(\mathrm{~s}), 965$ (s), $818(\mathrm{~s}), 783(\mathrm{~m}) \mathrm{cm}^{-1}$. UV-Vis $\left(\mathrm{CH}_{2} \mathrm{Cl}_{2}\right): \lambda_{\max } 507 \mathrm{~nm}(\varepsilon=$ 26,200 $\mathrm{M}^{-1} \mathrm{~cm}^{-1}$ ). Mass Spec. (EI, +ve mode): exact mass calculated for $\left[\mathrm{C}_{20} \mathrm{H}_{18} \mathrm{BF}_{2} \mathrm{~N}_{5}\right]^{+}$: 377.1623; exact mass found: 377.1633; difference: +2.6 ppm. Anal. Calcd. (\%) for $\mathrm{C}_{20} \mathrm{H}_{18} \mathrm{BF}_{2} \mathrm{~N}_{5}: \mathrm{C}, 63.68 ; \mathrm{H}, 4.81 ; \mathrm{N}, 18.57$. Found: $\mathrm{C}, 63.57 ; \mathrm{H}, 4.84 ; \mathrm{N}, 18.20$.

\section{$8 b$}

Yield $=0.84$ g, 38\%. M.p 221-223 ${ }^{\circ} \mathrm{C} .{ }^{1} \mathrm{H}$ NMR $\left(400.1 \mathrm{MHz}, \mathrm{CDCl}_{3}\right): \delta 8.75-8.69(\mathrm{~m}, 2 \mathrm{H}$, aryl $\mathrm{CH}), 8.19-8.16(\mathrm{~m}, 1 \mathrm{H}$, aryl $\mathrm{CH}), 7.87-7.86(\mathrm{~m}, 2 \mathrm{H}$, aryl $\mathrm{CH}), 7.68-7.67(\mathrm{~m}, 2 \mathrm{H}$, aryl $\mathrm{CH})$, 7.61-7.59 (m, 1H, aryl CH), $7.31\left(\mathrm{~d},{ }^{3} J_{\mathrm{HH}}=8 \mathrm{~Hz}, 2 \mathrm{H}\right.$, aryl $\left.\mathrm{CH}\right), 7.20\left(\mathrm{~d},{ }^{3} J_{\mathrm{HH}}=8 \mathrm{~Hz}, 2 \mathrm{H}\right.$, aryl $\mathrm{CH}), 2.44\left(\mathrm{~s}, 3 \mathrm{H}, \mathrm{CH}_{3}\right), 2.37\left(\mathrm{~s}, 3 \mathrm{H}, \mathrm{CH}_{3}\right) .{ }^{13} \mathrm{C}\left\{{ }^{1} \mathrm{H}\right\} \mathrm{NMR}\left(150.7 \mathrm{MHz}, \mathrm{CDCl}_{3}\right): \delta 151.4,143.3$, 141.7, 141.5, 141.3, 140.4, 139.4, 135.3, 129.8, 129.5, 123.3, 123.0, 121.8, 120.9, 21.6, 21.0.

${ }^{11} \mathrm{~B}$ NMR $\left(128.3 \mathrm{MHz}, \mathrm{CDCl}_{3}\right): \delta 0.4\left(\mathrm{t},{ }^{1} J_{\mathrm{BF}}=32 \mathrm{~Hz}\right) .{ }^{19} \mathrm{~F}$ NMR $\left(376.1 \mathrm{MHz}, \mathrm{CDCl}_{3}\right): \delta-137.9$ $\left(\mathrm{q},{ }^{1} J_{\mathrm{FB}}=32 \mathrm{~Hz}\right)$. FT-IR(ATR): $3008(\mathrm{w}), 2914(\mathrm{w}), 1619(\mathrm{~m}), 1567(\mathrm{~m}), 1476(\mathrm{~m}), 1412(\mathrm{~m})$, 1317 (m), 1277 (m), 1125 (m), 1080 (s), 1028 (s), 972 (m), 820 (m), 774 (s) cm ${ }^{-1}$. UV-Vis $\left(\mathrm{CH}_{2} \mathrm{Cl}_{2}\right): \lambda_{\max } 331 \mathrm{~nm}\left(\varepsilon=13,700 \mathrm{M}^{-1} \mathrm{~cm}^{-1}\right), 457 \mathrm{~nm}\left(\varepsilon=26,600 \mathrm{M}^{-1} \mathrm{~cm}^{-1}\right)$. Mass Spec. (EI, +ve mode): exact mass calculated for $\left[\mathrm{C}_{20} \mathrm{H}_{18} \mathrm{BF}_{2} \mathrm{~N}_{5}\right]^{+}$: 377.1623 ; exact mass found: 377.1628 ; difference: +1.3 ppm. Anal. Calcd. (\%) for $\mathrm{C}_{20} \mathrm{H}_{18} \mathrm{BF}_{2} \mathrm{~N}_{5}$ : C, 63.68; H, 4.81; N, 18.57. Found: $\mathrm{C}$, $63.36 ; \mathrm{H}, 4.80 ; \mathrm{N}, 18.20$.

\section{$\mathbf{8 a} \cdot \mathbf{H}^{+}$}

8a $(0.050 \mathrm{~g}, 0.13 \mathrm{mmol})$ was dissolved in $\mathrm{EtOH}(10 \mathrm{~mL})$ and $p$-TsOH $(1.14 \mathrm{~g}, 5.99 \mathrm{mmol})$ in EtOH $(10 \mathrm{~mL})$ was added. The solution was stirred for $30 \mathrm{~min}$ and then concentrated in vacuo. The resulting residue was dissolved in $\mathrm{CH}_{2} \mathrm{Cl}_{2}(25 \mathrm{~mL})$, washed with deionized $\mathrm{H}_{2} \mathrm{O}(25 \mathrm{~mL})$, 
dried over $\mathrm{MgSO}_{4}$, gravity filtered and concentrated in vacuo to yield a dark red microcrystalline solid. Yield $=0.060$ g, 84\%. M.p $121-123{ }^{\circ} \mathrm{C} .{ }^{1} \mathrm{H}$ NMR $\left(400.1 \mathrm{MHz}, \mathrm{CDCl}_{3}\right): \delta 9.47-9.46(\mathrm{~m}$, $1 \mathrm{H}$, aryl $\mathrm{CH}), 8.45-8.41(\mathrm{~m}, 2 \mathrm{H}$, aryl $\mathrm{CH}), 7.99\left(\mathrm{~d},{ }^{3} J_{\mathrm{HH}}=8 \mathrm{~Hz}, 4 \mathrm{H}\right.$, aryl $\left.\mathrm{CH}\right), 7.88-7.85(\mathrm{~m}$, $1 \mathrm{H}$, aryl $\mathrm{CH}), 7.74\left(\mathrm{~d},{ }^{3} \mathrm{~J}_{\mathrm{HH}}=7 \mathrm{~Hz}, 2 \mathrm{H}, \operatorname{aryl} \mathrm{CH}\right), 7.18\left(\mathrm{~d},{ }^{3} J_{\mathrm{HH}}=8 \mathrm{~Hz}, 4 \mathrm{H}, \operatorname{aryl} \mathrm{CH}\right), 7.10(\mathrm{~d}$, ${ }^{3} J_{\mathrm{HH}}=7 \mathrm{~Hz}, 2 \mathrm{H}$, aryl $\left.\mathrm{CH}\right), 2.38\left(\mathrm{~s}, 6 \mathrm{H}, \mathrm{CH}_{3}\right), 2.33\left(\mathrm{~s}, 3 \mathrm{H}, \mathrm{CH}_{3}\right) .{ }^{13} \mathrm{C}\left\{{ }^{1} \mathrm{H}\right\} \operatorname{NMR}(150.7 \mathrm{MHz}$, $\left.\mathrm{CDCl}_{3}\right): \delta 146.3,145.8,143.5,143.1,142.6,141.6,141.3,140.4,130.3,128.9,126.3,125.6$, 123.7, 122.9, 21.6, 21.4. ${ }^{11} \mathrm{~B}$ NMR $\left(128.3 \mathrm{MHz}, \mathrm{CDCl}_{3}\right): \delta-0.6\left(\mathrm{t},{ }^{1} J_{\mathrm{BF}}=30 \mathrm{~Hz}\right) .{ }^{19} \mathrm{~F} \mathrm{NMR}$ (376.1 MHz, $\mathrm{CDCl}_{3}$ ): $\delta-136.1$ (q, ${ }^{1} J_{\mathrm{FB}}=30 \mathrm{~Hz}$ ). FT-IR(ATR): 3357 (br, m), $3102(\mathrm{~m}), 2919$ (m), $2841(\mathrm{~m}), 1599$ (s), $1495(\mathrm{~m}), 1375$ (m), $1334(\mathrm{~s}), 1223(\mathrm{~m}), 1169$ (s), 1116 (s), $1000(\mathrm{~m})$, 967 (s), $811(\mathrm{~s}) \mathrm{cm}^{-1}$. UV-Vis $\left(\mathrm{CH}_{2} \mathrm{Cl}_{2}\right): \lambda_{\max } 533 \mathrm{~nm}\left(\varepsilon=23,000 \mathrm{M}^{-1} \mathrm{~cm}^{-1}\right)$. Mass Spec. (ESI, +ve mode): exact mass calculated for $\left[\mathrm{C}_{20} \mathrm{H}_{19} \mathrm{BF}_{2} \mathrm{~N}_{5}\right]^{+}$: 378.1701 ; exact mass found: 378.1708 ; difference: +1.8 ppm.

\section{9a}

In a $\mathrm{N}_{2}$ filled glovebox, adduct $8 \mathbf{a}(0.050 \mathrm{~g}, 0.13 \mathrm{mmol})$ was dissolved in dry and degassed toluene $(10 \mathrm{~mL}) .\left[\mathrm{Ni}(\mathrm{OTf})_{2}\right](0.024 \mathrm{~g}, 0.066 \mathrm{mmol})$ was suspended in dry and degassed toluene $(5 \mathrm{~mL})$ and added to the solution of $\mathbf{8 a}$. This mixture was heated at $60{ }^{\circ} \mathrm{C}$ with stirring for $18 \mathrm{~h}$ before it was removed from the glovebox and opened to ambient atmosphere. The mixture was then concentrated in vacuo to yield a dark red solid. This product was recrystallized by slow diffusion of pentane into a concentrated $\mathrm{CH}_{2} \mathrm{Cl}_{2}$ solution to yield complex $9 \mathbf{a}$ as red crystals. Yield $=0.068$ g, 89\%. M.p 249-251 ${ }^{\circ}$ C. FT-IR(ATR): 3294 (br, s), 3035 (m), 2921 (m), 2857 (m), $1605(\mathrm{~m}), 1588(\mathrm{~m}), 1355(\mathrm{~m}), 1316(\mathrm{~s}), 1296(\mathrm{~s}), 1222(\mathrm{~m}), 1178(\mathrm{~s}), 1128(\mathrm{~m}), 1023(\mathrm{~m})$, 
$970(\mathrm{~m}), 819(\mathrm{~m}) \mathrm{cm}^{-1}$. UV-Vis $\left(\mathrm{CH}_{2} \mathrm{Cl}_{2}\right): \lambda_{\max } 509 \mathrm{~nm}\left(\varepsilon=32,300 \mathrm{M}^{-1} \mathrm{~cm}^{-1}\right)$. Anal. Calcd. (\%) for $\mathrm{C}_{42} \mathrm{H}_{40} \mathrm{~B}_{2} \mathrm{~F}_{10} \mathrm{~N}_{10} \mathrm{O}_{8} \mathrm{~S}_{2} \mathrm{Ni}: \mathrm{C}, 43.97 ; \mathrm{H}, 3.51 ; \mathrm{N}, 12.21$. Found: C, 43.43; H, 3.77; N, 11.85 .

\section{$10 \mathbf{a}$}

Adduct $8 \mathbf{a}(0.050 \mathrm{~g}, 0.13 \mathrm{mmol})$ was dissolved in $\mathrm{CH}_{2} \mathrm{Cl}_{2}(25 \mathrm{~mL})$ and $\left[\mathrm{Ni}(\mathrm{hfac})_{2}\left(\mathrm{H}_{2} \mathrm{O}\right)_{2}\right](0.124$ $\mathrm{g}, 0.130 \mathrm{mmol}$ ) was added. The mixture was stirred overnight before it was filtered and the filtrate concentrated in vacuo. The resulting red/purple solid was recrystallized by slow diffusion of pentane into a concentrated $\mathrm{CH}_{2} \mathrm{Cl}_{2}$ solution of the reaction product to yield complex $\mathbf{1 0 a}$ as red/purple crystals. Yield $=0.081$ g, 72\%. M.p 230-232 ${ }^{\circ}$ C. FT-IR(ATR): 3346 (br, s), 2984 (m), $2871(\mathrm{~m}), 1641(\mathrm{~m}), 1478(\mathrm{~m}), 1255$ (m), $1200(\mathrm{~m}), 1127(\mathrm{~s}), 1055(\mathrm{~s}), 894(\mathrm{~m}), 818(\mathrm{w}), 790(\mathrm{~s})$, $750(\mathrm{~s}) \mathrm{cm}^{-1}$. UV-Vis $\left(\mathrm{CH}_{2} \mathrm{Cl}_{2}\right): \lambda_{\max } 535 \mathrm{~nm}\left(\varepsilon=23,700 \mathrm{M}^{-1} \mathrm{~cm}^{-1}\right)$. Mass Spec. (EI, +ve mode): exact mass calculated for $\left[\mathrm{C}_{30} \mathrm{H}_{20} \mathrm{BF}_{14} \mathrm{~N}_{5} \mathrm{O}_{4} \mathrm{Ni}\right]^{+}$: 849.0738; exact mass found: 849.0778; difference: +4.7 ppm. Anal. Calcd. (\%) for $\mathrm{C}_{30} \mathrm{H}_{20} \mathrm{BF}_{14} \mathrm{~N}_{5} \mathrm{O}_{4} \mathrm{Ni}$ : C, 42.39; H, 2.37; N, 8.24. Found: C, 42.50; H, 2.53; N, 7.94.

\section{0b}

Adduct $8 \mathbf{b}(0.050 \mathrm{~g}, 0.13 \mathrm{mmol})$ was dissolved in $\mathrm{CH}_{2} \mathrm{Cl}_{2}(25 \mathrm{~mL})$ and $\left[\mathrm{Ni}(\mathrm{hfac})_{2}\left(\mathrm{H}_{2} \mathrm{O}\right)_{2}\right](0.124$ $\mathrm{g}, 0.130 \mathrm{mmol}$ ) was added. The mixture was stirred overnight before it was filtered and the filtrate concentrated in vacuo. The resulting red solid was recrystallized by slow diffusion of pentane into a concentrated $\mathrm{CH}_{2} \mathrm{Cl}_{2}$ solution of the reaction product to yield complex $\mathbf{1 0 b}$ as red/orange crystals. Yield $=0.074$ g, 66\%. M.p 241-243 ${ }^{\circ} \mathrm{C}$. FT-IR(ATR): 3360 (br, s), 3141 (w), 2925 (m), 2870 (m), 1640 (m), 1479 (s), 1415 (w), 1341 (m), 1258 (s), 1196 (s), 1133 (s), 1032 (s), $790(\mathrm{~m}), 779(\mathrm{~m}), 672(\mathrm{~s}) \mathrm{cm}^{-1}$. UV-Vis $\left(\mathrm{CH}_{2} \mathrm{Cl}_{2}\right): \lambda_{\max } 383 \mathrm{~nm}\left(\varepsilon=21,400 \mathrm{M}^{-1} \mathrm{~cm}^{-1}\right)$, 
$526 \mathrm{~nm}\left(\varepsilon=24,100 \mathrm{M}^{-1} \mathrm{~cm}^{-1}\right)$. Mass Spec. (EI, +ve mode): exact mass calculated for $\left[\mathrm{C}_{30} \mathrm{H}_{20} \mathrm{BF}_{14} \mathrm{~N}_{5} \mathrm{O}_{4} \mathrm{Ni}\right]^{+}$: 849.0738; exact mass found: 849.0718; difference: $-2.4 \mathrm{ppm}$. Anal. Calcd. (\%) for $\mathrm{C}_{30} \mathrm{H}_{20} \mathrm{BF}_{14} \mathrm{~N}_{5} \mathrm{O}_{4} \mathrm{Ni}$ : C, 42.39; H, 2.37; N, 8.24. Found: C, 42.36; H, 2.59; N, 7.85.

\section{Results and Discussion}

Formazan 7 was synthesized by adapting a published procedure (Scheme S1, Figure S2, S3). ${ }^{57}$ The subsequent reaction with $\mathrm{BF}_{3} \bullet \mathrm{OEt}_{2}$ and $\mathrm{NEt}_{3}$ (Scheme 1) afforded two products which could be separated by column chromatography $\left(\mathrm{CH}_{2} \mathrm{Cl}_{2}\right.$, silica gel). Adduct $\mathbf{8 a}\left(R_{f}=0.35,31 \%\right.$ yield $)$ resembled other $\mathrm{BF}_{2}$ formazanate adducts with the aryl-substituted nitrogens coordinated to the ' $\mathrm{BF}_{2}$ ' fragment. ${ }^{37}$ Adduct $\mathbf{8 b}\left(R_{f}=0.88,38 \%\right.$ yield $)$ contained a ' $\mathrm{BF}_{2}$ ' fragment chelated by one of the aryl-substituted nitrogen atoms of the formazanate backbone as well as the nitrogen of the pyridine substituent. Several coordination modes between boron and formazanate ligands have been reported, ${ }^{45,46}$ though the connectivity present in $\mathbf{8 b}$ has not been observed previously. When stirred in the presence of Lewis bases such as 4-dimethylaminopyridine, interconversion from $8 \mathbf{a}$ to $\mathbf{8 b}$ and vice versa was not observed. Adduct $\mathbf{8 b}$ contains a potentially photoactive azotoluene moiety. However, irradiation with $365-370 \mathrm{~nm}$ or $525-530 \mathrm{~nm}$ light and temperature variation did not result in observable $E \rightarrow Z$ isomerization. This behavior was in stark contrast to that observed for arylazoindazoles, derived from related formazans, which readily isomerize under similar conditions. ${ }^{58}$

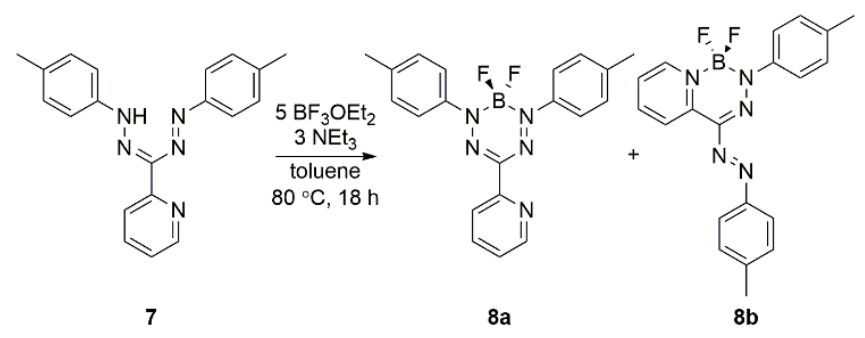

Scheme 1. Synthesis of $\mathrm{BF}_{2}$ adducts $8 \mathbf{a}$ and $\mathbf{8 b}$. 
The isolated adducts were characterized by ${ }^{1} \mathrm{H},{ }^{11} \mathrm{~B},{ }^{13} \mathrm{C}\left\{{ }^{1} \mathrm{H}\right\}$ and ${ }^{19} \mathrm{~F}$ NMR, IR and UV-vis spectroscopy, elemental analysis and mass spectrometry. In both 8a and 8b, 1:2:1 triplets and 1:1:1:1 quartets were observed in the respective ${ }^{11} \mathrm{~B}$ and ${ }^{19} \mathrm{~F}$ NMR spectra, confirming the presence of the $\mathrm{BF}_{2}$ moiety (Figure S4-S7). However, the chemical shifts of the signals were quite different ( ${ }^{11}$ B: 8a,,-0.6 ppm; 8b, 0.4 ppm. ${ }^{19}$ F: 8a, -144.8 ppm; 8b, -137.9 ppm). Both adducts were also characterized by single crystal X-ray crystallography (Figure 1). The bond lengths and angles observed in $\mathbf{8 a}$ are structurally similar to other $\mathrm{BF}_{2}$ adducts of triarylformazanate ligands, ${ }^{37}$ including delocalization of electron density over the entire N-N=C$\mathrm{N}=\mathrm{N}$ backbone and a slight displacement (by $0.565 \AA$ ) of the boron atom from the $\mathrm{N}_{4}$ plane. In $\mathbf{8 b}$, the electron density in the $\pi$ system of the chelate ring is also delocalized, with the N-N, C-C and $\mathrm{C}-\mathrm{N}$ bond lengths between the expected single and double bond lengths for the respective atoms involved. ${ }^{59}$ Interestingly, electronic delocalization does not extend into the azotoluene portion of the molecule [C1-N4 1.408(2) $\AA$, N4-N3 1.239(2) $\AA$ ]. The boron atom is displaced in the solid-state structure of $\mathbf{8 b}$ from the N1, N2, N5, C16 plane by $0.394 \AA$.

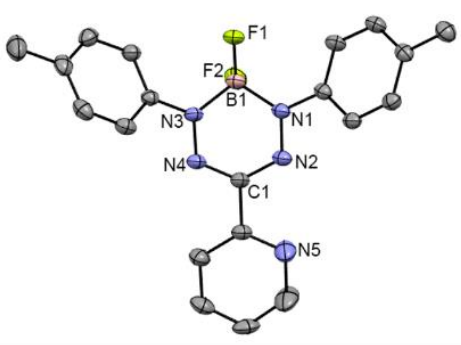

$8 a$

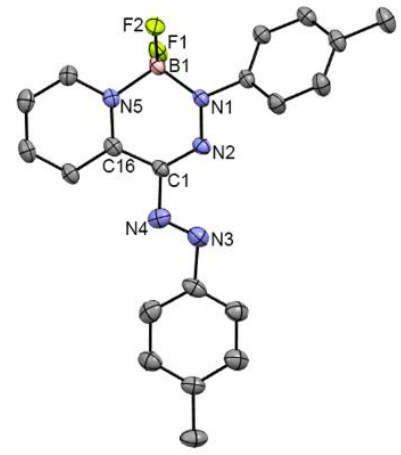

$8 b$

Figure 1. Solid-state structures of $\mathbf{8 a}$ and $\mathbf{8 b}$. Anisotropic displacement ellipsoids are shown at $50 \%$ probability and hydrogen atoms have been removed for clarity.

Adducts 8a and $\mathbf{8 b}$ are strongly absorbing over much of the visible region in $\mathrm{CH}_{2} \mathrm{Cl}_{2}$ (Figure 2, Table 2). Adduct $8 \mathbf{a}$ has a wavelength of maximum absorption $\left(\lambda_{\max }\right)$ of $507 \mathrm{~nm}$, typical of $\mathrm{BF}_{2}$ 
adducts of triarylformazanate ligands. ${ }^{37}$ Adduct $\mathbf{8 b}$ exhibits two low-energy maxima at 404 and $457 \mathrm{~nm}$, which are of similar intensity relative to the maxima observed for $\mathbf{8 a}$. The absorption spectra of $\mathbf{8 a}$ and $\mathbf{8 b}$ in toluene and THF are unchanged relative to those collected in $\mathrm{CH}_{2} \mathrm{Cl}_{2}$, indicating that the absorption maxima likely arise due to $\pi \rightarrow \pi^{*}$ transitions rather than charge transfer. Both $\mathbf{8 a}$ and $\mathbf{8 b}$ are essentially non-emissive, with fluorescence quantum yields $\left(\Phi_{\mathrm{F}}\right)$ less than $1 \%$.

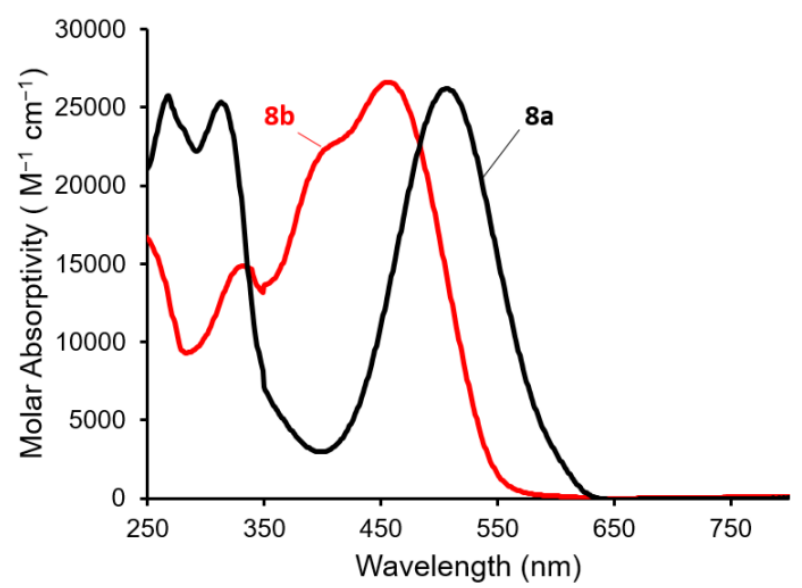

Figure 2. UV-vis absorption spectra of $\mathbf{8 a}$ and $\mathbf{8 b}$ in $\mathrm{CH}_{2} \mathrm{Cl}_{2}$.

Table 2. Solution properties of $8 \mathbf{a}, 8 \mathbf{b}, 9 \mathbf{a}, 10 \mathrm{a}$ and $10 \mathbf{b}$ in $\mathrm{CH}_{2} \mathrm{Cl}_{2}$.

\begin{tabular}{lllllc}
\hline & $\lambda_{\max }(\mathrm{nm})$ & $\varepsilon\left(\mathrm{M}^{-1} \mathrm{~cm}^{-1}\right)$ & $\mathrm{E}_{\text {red1 }}(\mathrm{V})^{a}$ & $\mathrm{E}_{\text {red2 }}(\mathrm{V})^{a}$ & $\mathrm{E}_{\text {red3 }}(\mathrm{V})^{a}$ \\
\hline $\mathbf{8 a}$ & 517 & 26,200 & -0.99 & $-2.00^{b}$ & - \\
$\mathbf{8 b}$ & 467,331 & $26,600,13,700$ & -1.53 & $-2.09^{b}$ & - \\
9a & 509 & 32,300 & -0.31 & -0.99 & -1.46 \\
10a & 539 & 26,700 & -0.64 & $-1.66^{b}$ & - \\
10b & 527,383 & $24,100,21,400$ & -0.92 & -1.18 & - \\
\hline
\end{tabular}

${ }^{a}$ Cyclic voltammetry experiments were conducted in $\mathrm{CH}_{2} \mathrm{Cl}_{2}$ containing $1 \mathrm{mM}$ analyte and $0.1 \mathrm{M}$ $\left[n \mathrm{Bu}_{4} \mathrm{~N}\right]\left[\mathrm{PF}_{6}\right]$ as supporting electrolyte at a scan rate of $100 \mathrm{mV} \mathrm{s}^{-1}$. All voltammograms were referenced internally against the ferrocene/ferrocenium redox couple. ${ }^{b}$ Irreversible peak, potential at maximum cathodic current reported.

Adducts $\mathbf{8 a}$ and $\mathbf{8 b}$ are electrochemically active (Figure 3, Table 2). Both adducts exhibit a reversible one-electron reduction wave $\left(\mathbf{8 a}: \mathrm{E}_{\text {red } 1}=-0.99 \mathrm{~V} ; \mathbf{8 b}: \mathrm{E}_{\text {red1 }}=-1.53 \mathrm{~V}\right)$ and a second irreversible reduction wave $\left(\mathbf{8 a}: \mathrm{E}_{\mathrm{pc}}=-2.00 \mathrm{~V} ; \mathbf{8 b}: \mathrm{E}_{\mathrm{pc}}=-2.09 \mathrm{~V}\right)$. The separation of these 
waves was much larger for $8 \mathbf{a}(\Delta \mathrm{E}=1.01 \mathrm{~V})$ than $\mathbf{8 b}(\Delta \mathrm{E}=0.56 \mathrm{~V})$. The electrochemical behavior of $\mathbf{8 a}$ is consistent with that of other triarylformazanate $\mathrm{BF}_{2}$ adducts, ${ }^{37}$ and the electrochemical behavior of $\mathbf{8 b}$ is comparable to related azo-benzene species. ${ }^{60}$

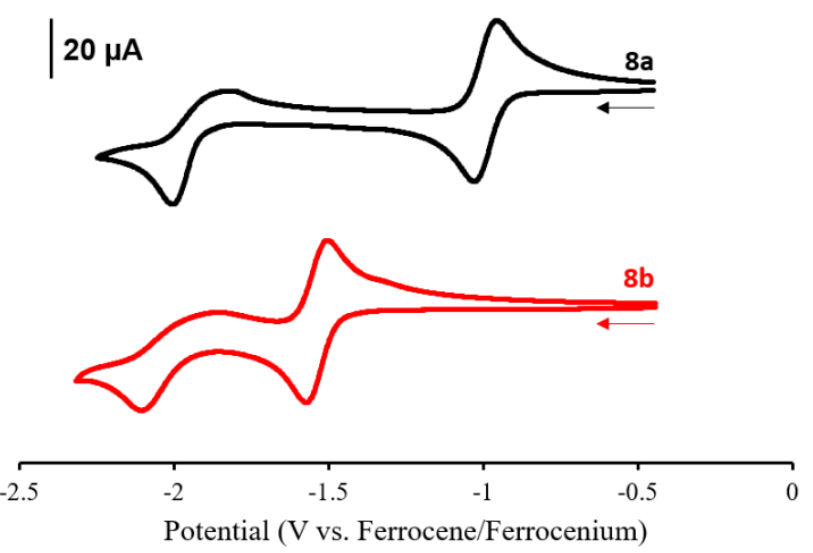

Figure 3. Cyclic voltammograms of $\mathbf{8 a}$ and $\mathbf{8 b}$ recorded at a scan rate of $100 \mathrm{mV} \mathrm{s}^{-1}$ in $1 \mathrm{mM}$ $\mathrm{CH}_{2} \mathrm{Cl}_{2}$ solutions containing $0.1 \mathrm{M}\left[n \mathrm{Bu}_{4} \mathrm{~N}\right]\left[\mathrm{PF}_{6}\right]$ as supporting electrolyte.

\section{Protonation Chemistry}

We have long postulated that the emission intensity observed for $\mathrm{BF}_{2}$ adducts of triarylformazanate ligands is attenuated by non-radiative relaxation pathways associated with rotation and/or vibration of the 3-aryl substituents. ${ }^{39}$ We therefore chose to explore protonation chemistry using $p$-toluenesulfonic acid $(p-\mathrm{TsOH})$ as a method for limiting vibration/rotation in 8a. A change in the colour of solutions of $\mathbf{8 a}$ and shifts in the corresponding ${ }^{1} \mathrm{H}$ NMR spectra were observed under acidic conditions. The fluorescence intensity also increased significantly upon acidification of solutions of $\mathbf{8 a}$. The $\mathrm{pH}$ dependence of fluorescence was therefore studied, revealing a linear increase in fluorescence intensity with decreasing $\mathrm{pH}$ (Figure 4). 

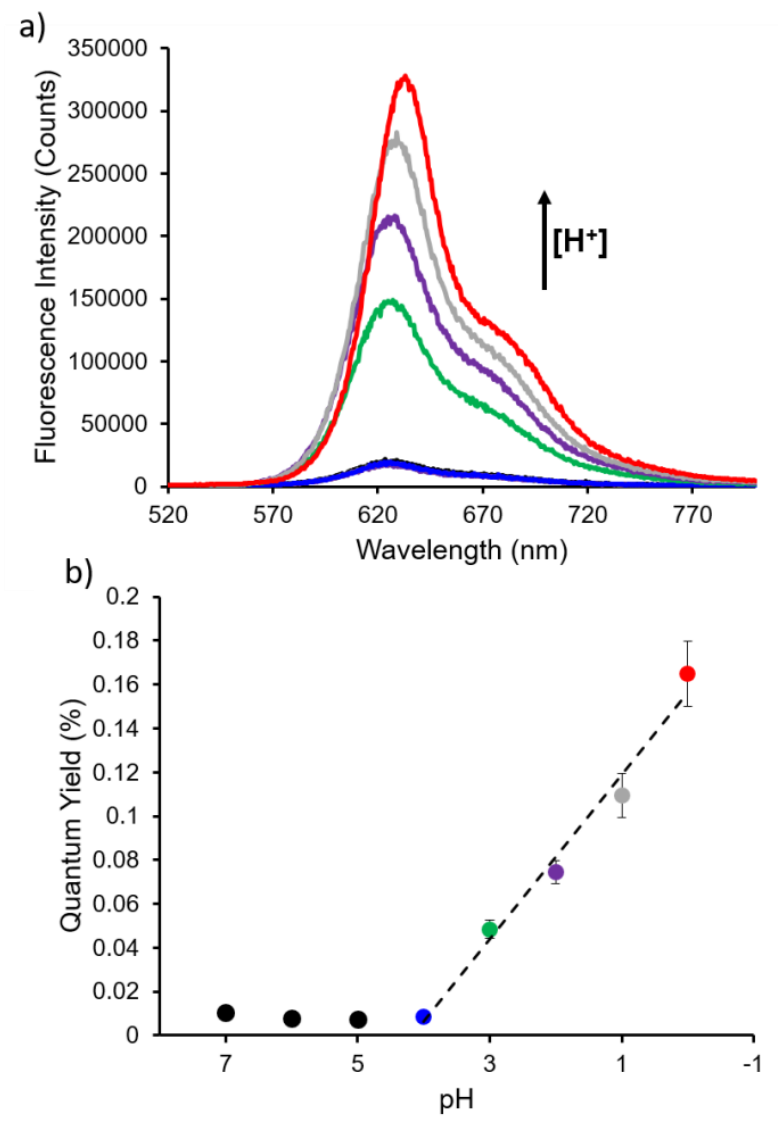

Figure 4. (a) Emission spectra of 8a at various pHs in 9:1 $\mathrm{H}_{2} \mathrm{O}$ :THF. (b) Change in $\Phi_{\mathrm{F}}$ of $\mathbf{8 a}$ as a function of $\mathrm{pH}$. The black dashed line is a line of best fit. Error bars were obtained from 3 independent measurements.

At $\mathrm{pH}>4, \Phi_{\mathrm{F}}$ remained constant at $\sim 1 \%$. However, at lower $\mathrm{pH}, \Phi_{\mathrm{F}}$ increased to a maximum value of $18 \%$. This represents the highest reported $\Phi_{\mathrm{F}}$ to date for a $\mathrm{BF}_{2}$ adduct of a triarylformazanate ligand, and corroborates our previous hypothesis surrounding the role of the 3- aryl substituent as a fluorescence attenuator. We also observed a slight red-shift in the wavelength of maximum emission $\left(\lambda_{\mathrm{em}}\right)$ as the fluorescence intensity increased, from $626 \mathrm{~nm}$ at $\mathrm{pH} 4$ to $633 \mathrm{~nm}$ at $\mathrm{pH} 0$. This is consistent with a change in the wavelength of maximum absorption upon decrease of $\mathrm{pH}$ in the absorption spectra from $507 \mathrm{~nm}(\mathrm{pH}$ 4) to $540 \mathrm{~nm}(\mathrm{pH} 0)$ (Figure S8). After isolation of the protonated adduct, the 1:1:1:1 quartet and 1:2:1 triplet in the ${ }^{19} \mathrm{~F}$ and ${ }^{11} \mathrm{~B}$ NMR spectra were retained, and ${ }^{1} \mathrm{H}$ and ${ }^{13} \mathrm{C}$ NMR shifts were similar (Figures S9, 
S10), implying the connectivity within the structure of the resulting adduct $\left(\mathbf{8} \cdot \mathbf{}^{+} \mathbf{H}^{+}\right)$had not changed. Upon protonation of the pyridine moiety at low $\mathrm{pH}$, inter- or intramolecular hydrogenbonding with nearby formazanate molecules, counter ions, and solvent molecules is likely. This potentially restricts vibration and rotation of the pyridine substituent, minimizing non-radiative relaxation pathways. The presence of hydrogen-bonding was confirmed in the solid state through single crystal X-ray crystallography (Figure 5). A hydrogen atom attached to the pyridyl nitrogen was observed. Many hydrogen bonds were also observed, including from the pyridine $\mathrm{N}-\mathrm{H}$ to a p-toluenesulfonate counter ion [N5-O1: 2.815(10) $\AA$ ]. All bond lengths and angles in the solidstate structures of $\mathbf{8 a}$ and $\mathbf{8 a} \cdot \mathbf{H}^{+}$are similar (Table 3). In the case of $\mathbf{8 b}$, no change was observed in the ${ }^{1} \mathrm{H}$ NMR and UV-vis absorption spectra, even upon exposure to concentrated $\mathrm{HCl}$ and $p$ $\mathrm{TsOH}$, indicating that protonation did not occur.

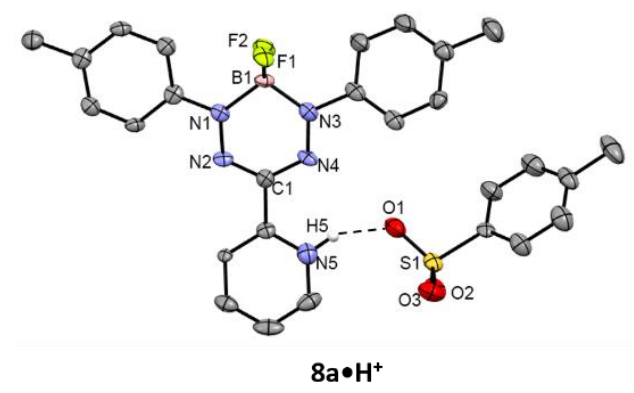

Figure 5. Solid-state structure of $\mathbf{8} \cdot \cdot \mathbf{H}^{+}$. Anisotropic displacement ellipsoids are shown at $50 \%$ probability and hydrogen atoms aside from $\mathrm{H} 5$, as well as a co-crystallized $p$-TsOH and $\mathrm{H}_{2} \mathrm{O}$ molecules have been removed for clarity. The dashed line indicates a hydrogen bond.

\section{Nickel(II) Coordination Chemistry}

Both $\mathbf{8 a}$ and $\mathbf{8 b}$ have the potential to act as bidentate $N$-donor ligands. We therefore attempted to study their coordination chemistry as a method for modulating their physical and electronic 
properties. This reactivity was probed using several nickel(II) sources, as we intended to probe the effect of metal coordination on ligand properties in the absence of metal-based redox reactivity. Initial attempts employed $\left[\mathrm{NiBr}_{2}\left(\mathrm{CH}_{3} \mathrm{CN}\right)_{2}\right]$ as a nickel(II) source. The resulting UVvis absorption and NMR spectra collected for the reaction mixture were unchanged compared to that of adducts $8 \mathbf{a}$ and $\mathbf{8 b}$, and the presence of two distinct solids upon removal of the solvent in each case indicated that $\mathrm{NiBr}_{2}$ had not bound the ligands employed. Next, [Ni(OTf $)_{2}$ ] was employed. In this case, a reaction was observed between $\left[\mathrm{Ni}(\mathrm{OTf})_{2}\right]$ and 8a, resulting in the formation of complex 9a. Single-crystal X-ray diffraction studies revealed a 2:1 ratio between 8a and nickel(II) (Figure 6), with two $\mathrm{H}_{2} \mathrm{O}$ molecules, oriented cis to one another, completing the octahedral coordination sphere of nickel(II). Attempts to alter the ratio of $\mathbf{8 a}$ to nickel(II) to 1:1 or 3:1, as well as attempts to isolate a nickel(II) complex via reaction with $\left[\mathrm{Ni}(\mathrm{OTf})_{2}\right]$ and $\mathbf{8 b}$ were unsuccessful. Finally, reactions with $\left[\mathrm{Ni}(\mathrm{hfac})_{2}\left(\mathrm{H}_{2} \mathrm{O}\right)_{2}\right] \quad(\mathrm{hfac}=1,1,1,6,6,6-$ hexafluoroacetylacetonate), were attempted. $\mathrm{BF}_{2}$ adducts $\mathbf{8 a}$ and $\mathbf{8 b}$ coordinated to the $\mathrm{Ni}(\mathrm{hfac})_{2}$ fragment and paramagnetic octahedral complexes $10 \mathrm{a}$ and $\mathbf{1 0 b}$ containing one $\mathrm{BF}_{2}$ adduct and two hfac ligands were isolated in both cases (Figure 6). The N3-N4 bond lengthened upon coordination to nickel(II) from 1.3135(17) $\AA$ in 8a to 1.326(3) in complex 9a, although there was no statistical difference between the N3-N4 bond lengths in 8a and 10a [1.328(10) Å]. Similarly, the N3-N4 bond lengthened from 1.239(2) $\AA$ in $\mathbf{8 b}$ to 1.336(6) $\AA$ in $\mathbf{1 0 b}$ (Table 3). The N-Ni-N angle is smaller in $\mathbf{1 0 b}\left[75.5(2)^{\circ}\right]$ than in $\mathbf{9 a}$ [average of $\left.77.90(8)^{\circ}\right]$ and $\mathbf{1 0 a}\left[77.6(3)^{\circ}\right]$, though all are less than the ideal $90^{\circ}$ angle expected for octahedral nickel(II). The average N-Ni bond lengths for 9a $[2.115(2) \AA]$, 10a [2.103(8) $\AA]$, and 10b [2.124(5) $\mathrm{A}]$ were not statistically different. The smaller angle and longer bonds observed in $\mathbf{1 0 b}$ may hint to why coordination is 
less favorable with this ligand, and unsuccessful when $\left[\mathrm{NiBr}_{2}\left(\mathrm{CH}_{3} \mathrm{CN}\right)_{2}\right]$ and $\left[\mathrm{Ni}(\mathrm{OTf})_{2}\right]$ were employed as nickel(II) sources.

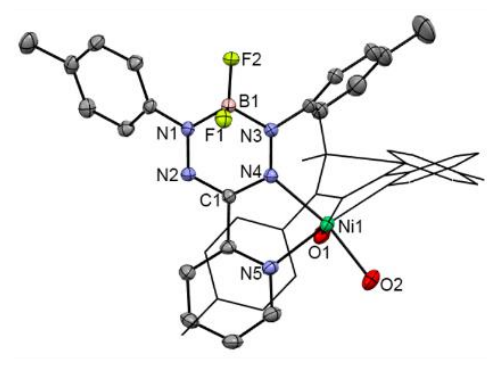

9a: $\left[\mathrm{Ni}(8 \mathrm{a})_{2}\left(\mathrm{OH}_{2}\right)_{2}\right]^{2+}$

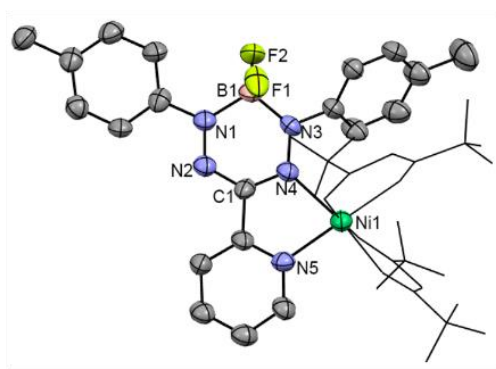

10a: $\left[\mathrm{Ni}(8 \mathrm{a})(\mathrm{hfac})_{2}\right]$

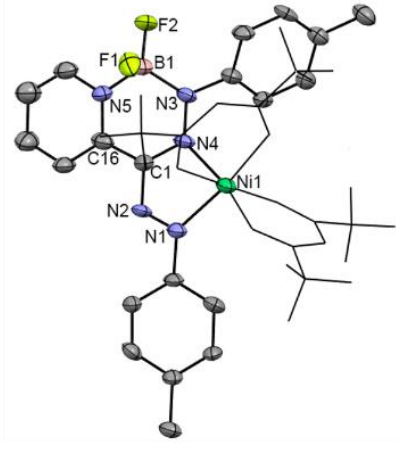

10b: $\left[\mathrm{Ni}(8 \mathrm{~b})(\mathrm{hfac})_{2}\right]$

Figure 6. Solid-state structures of 9a, 10a, and 10b. Anisotropic displacement ellipsoids are shown at 50\% probability and hydrogen atoms as well as the triflate counterions (9a) and cocrystallized solvent $(\mathbf{9 a}, \mathbf{1 0 a})$ have been removed for clarity. The second $\mathrm{BF}_{2}$ adduct of $9 \mathbf{a}$ and the hfac ligands of 10a and $10 \mathbf{b}$ have been made wireframe for clarity.

Table 3. Selected bond lengths $(\mathrm{A})$ and angles $\left(^{\circ}\right)$ for $8 \mathbf{a}, \mathbf{8 a} \cdot \mathbf{H}^{\mathbf{+}}, \mathbf{8 b}, 9 \mathbf{a}, \mathbf{1 0 a}$, and $10 \mathbf{b}$.

\begin{tabular}{|c|c|c|c|c|c|c|c|}
\hline & \multirow{2}{*}{$8 a$} & \multirow{2}{*}{$8 \mathbf{a} \cdot \mathbf{H}^{+}$} & \multirow{2}{*}{$8 b$} & \multicolumn{2}{|c|}{$9 a$} & \multirow{2}{*}{$10 \mathrm{a}$} & \multirow{2}{*}{$10 b$} \\
\hline & & & & Ligand 1 & Ligand 2 & & \\
\hline N1-N2 & $1.3160(17)$ & $1.309(6)$ & $1.337(2)$ & $1.306(3)$ & $1.304(3)$ & $1.309(10)$ & $1.269(7)$ \\
\hline N3-N4 & $1.3135(17)$ & $1.307(6)$ & $1.239(2)$ & $1.325(3)$ & $1.327(3)$ & $1.328(10)$ & $1.336(6)$ \\
\hline C1-N2 & $1.337(2)$ & $1.326(7)$ & $1.312(2)$ & $1.345(3)$ & $1.342(3)$ & $1.330(11)$ & $1.387(7)$ \\
\hline C1-N4 & $1.340(2)$ & $1.346(7)$ & $1.408(2)$ & $1.340(3)$ & $1.342(3)$ & $1.344(11)$ & $1.324(8)$ \\
\hline C1-C16 & $1.487(2)$ & $1.473(8)$ & $1.456(3)$ & $1.473(3)$ & $1.473(3)$ & $1.481(13)$ & $1.432(9)$ \\
\hline C16-N5 & $1.363(2)$ & $1.352(7)$ & $1.354(2)$ & $1.348(3)$ & $1.345(3)$ & $1.331(12)$ & $1.367(7)$ \\
\hline N4-Ni1 & - & - & - & $2.136(2)$ & $2.176(2)$ & $2.171(8)$ & $2.157(5)$ \\
\hline N5-Ni1 & - & - & - & $2.070(2)$ & $2.079(2)$ & $2.035(8)$ & - \\
\hline N1-Nil & - & - & - & - & - & - & $2.091(5)$ \\
\hline N4-Ni1-N5 & - & - & - & $78.06(8)$ & 77.74(8) & $77.6(3)$ & - \\
\hline N1-Ni1-N4 & - & - & - & - & - & - & $75.5(2)$ \\
\hline
\end{tabular}

All three nickel(II) complexes absorb strongly between 450 and $600 \mathrm{~nm}$ (Figure 7, Table 2). The molar absorptivity of $\mathbf{9 a}$ is significantly higher than that of $\mathbf{1 0 a}$ or $\mathbf{1 0 b}$, due to the presence of two $\mathrm{BF}_{2}$ adducts in the complex. The $\lambda_{\max }$ of $\mathbf{9 a}$ is essentially unchanged from that of the parent ligand 8a (509 and $517 \mathrm{~nm}$, respectively). In contrast, the $\lambda_{\max }$ values are shifted significantly in the complexes which are coordinated to $\mathrm{Ni}(\mathrm{hfac})_{2}\left(\mathbf{1 0 a}: \Delta \lambda_{\max }=-22 \mathrm{~nm} ; \mathbf{1 0 b}: \Delta \lambda_{\max }=50 \mathrm{~nm}\right)$. In complex 10b, a second intense absorption at a wavelength of $389 \mathrm{~nm}$ was also observed. 
Despite the rigidification of the pyridine substituent by nickel(II) coordination, each of the nickel(II) complexes were non-emissive.

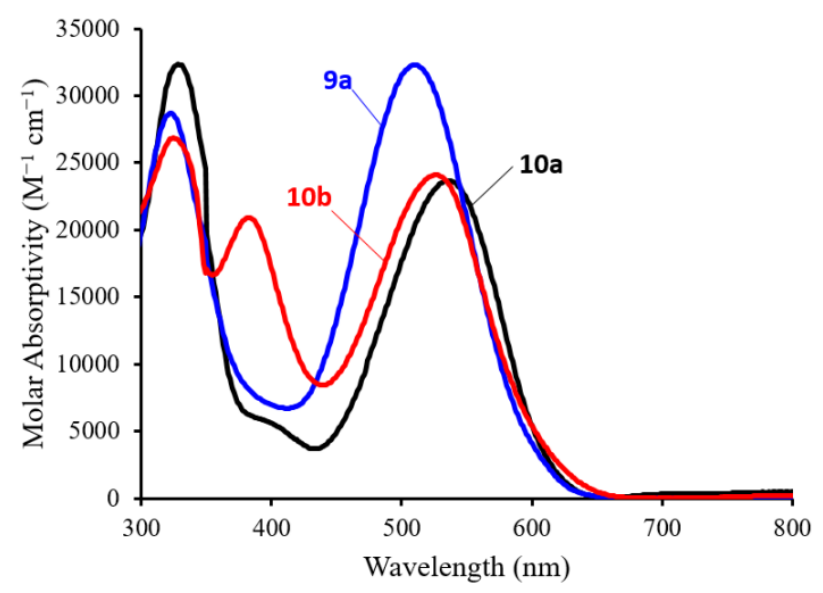

Figure 7. UV-vis absorption spectra of 9a, 10a, and $10 \mathbf{b}$ in $\mathrm{CH}_{2} \mathrm{Cl}_{2}$.

Nickel(II) complexes 9a, 10a and $\mathbf{1 0 b}$ are electrochemically active (Figure 8, Table 2). Complex 9a was reversibly reduced by two electrons at $-0.31 \mathrm{~V}$, and reversibly reduced by one electron at $-0.99 \mathrm{~V}$ and $-1.46 \mathrm{~V}$ (Scheme 2). The two-electron reduction corresponds to each of the nickel(II)-bound $\mathrm{BF}_{2}$ adducts being converted to ligand-centered radical anions. This reduction takes place at a significantly lower potential than the free ligand (by $c a .0 .68 \mathrm{~V}$ ). The two additional one-electron reductions observed correspond to the stepwise reduction of the $\mathrm{BF}_{2}$ ligands to their ligand-centered dianion forms. The ligand-centered reduction behavior is consistent with that of other $\mathrm{BF}_{2}$ formazanate adducts ${ }^{37,41}$ and the non-coincident reduction waves imply that the electron-rich nature of the formally trianionic complex resulting from the reduction at $-0.99 \mathrm{~V}$ has a significant influence over the subsequent reduction step. Both events occur at less negative potentials than the corresponding events observed for 8a. These findings confirm that the electron-withdrawing nickel(II) makes the $\mathrm{BF}_{2}$ adduct more electron poor, and thus easier to reduce. 


$$
\left[\mathrm{Ni}\left(\mathbf{8} \mathbf{a}^{2-}\right)_{2}\left(\mathrm{OH}_{2}\right)_{2}\right]^{2-} \underset{+\mathrm{e}^{-}}{\stackrel{-\mathrm{e}^{-}}{+}}\left[\mathrm{Ni}\left(\mathbf{8} \mathbf{a}^{-}\right)\left(\mathbf{8} \mathbf{a}^{2-}\right)\left(\mathrm{OH}_{2}\right)_{2}\right]^{-\frac{-\mathrm{e}^{-}}{+\mathrm{e}^{-}}}\left[\mathrm{Ni}\left(\mathbf{8} \mathbf{a}^{--}\right)_{2}\left(\mathrm{OH}_{2}\right)_{2}\right] \underset{+2 \mathrm{e}^{-}}{\stackrel{-2 \mathrm{e}^{-}}{\longrightarrow}}\left[\mathrm{Ni}(\mathbf{8 a})_{2}\left(\mathrm{OH}_{2}\right)_{2}\right]^{2+}
$$

Scheme 2. Electrochemical reduction of nickel(II) complex 9a. The charge on ligand 8a has been specified for clarity.

Similarly, two ligand-centered reductions were observed at potentials of $-0.64 \mathrm{~V}$ and $-1.58 \mathrm{~V}$ in the cyclic voltammogram collected for 10a. Again, both of these reduction processes occur more easily than those observed for $\mathbf{8 a}$. However, $\mathbf{1 0 a}$ is not as easy to reduce as $\mathbf{9 a}\left(\mathbf{8 a}\right.$ : $\mathrm{E}_{\mathrm{red} 1}=-0.99$ $\mathrm{V} ;$ 9a: $\left.\mathrm{E}_{\mathrm{red} 1}=-0.31 \mathrm{~V} ; \mathbf{1 0 a}: \mathrm{E}_{\mathrm{red} 1}=-0.64 \mathrm{~V}\right)$. Two reduction events were also present in the $\mathrm{CV}$ of $\mathbf{1 0 b}$, albeit at much less negative potentials.

Similar to the nickel(II) complexes of $\mathrm{BF}_{2}$ adduct $\mathbf{8 a}$, each process was observed at less negative potentials (shifted by 0.61 and $0.91 \mathrm{~V}$ respectively) compared to the free ligand. As a result, the second reduction was reversible in metal complex $\mathbf{1 0 b}$, whereas it was irreversible in $\mathbf{8 b}$. Scanning to further negative potentials in $\mathbf{1 0 a}$ and $\mathbf{1 0 b}$, an irreversible reduction is observed, which can be attributed to reduction of the hfac ligands (Figure S11). ${ }^{61}$

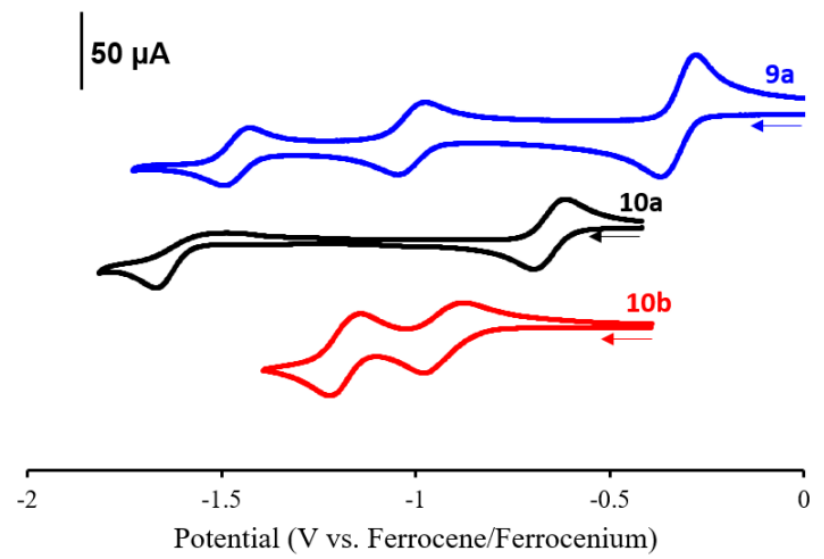

Figure 8. Cyclic voltammograms of $9 \mathbf{a}, \mathbf{1 0 a}$ and $\mathbf{1 0 b}$ recorded at a scan rate of $100 \mathrm{mV} \mathrm{s}^{-1}$ in 1 $\mathrm{mM} \mathrm{CH} \mathrm{Cl}_{2}$ solutions containing $0.1 \mathrm{M}\left[n \mathrm{Bu}_{4} \mathrm{~N}\right]\left[\mathrm{PF}_{6}\right]$ as supporting electrolyte. 


\section{Conclusions}

In conclusion, we have synthesized a pyridine-substituted triarylformazanate ligand that can adopt two different coordination modes upon reaction with sources of ' $\mathrm{BF}_{2}$ '. The first adduct, $\mathbf{8 a}$, coordinated to the $\mathrm{BF}_{2}$ through the aryl-substituted nitrogens of the formazanate backbone, and contained a pyridine substituent. The second adduct, $\mathbf{8 b}$, coordinated through one of the formazanate nitrogens, as well as through the pyridine nitrogen, and beared an azotoluene substituent. The free pyridine moiety in $\mathbf{8 a}$ could be protonated, and upon protonation, the $\Phi_{\mathrm{F}}$ increased substantially to a maximum of $18 \%$. The use of complex $\mathbf{8 a}$ as a fluorescent $\mathrm{pH}$ sensor was also demonstrated, with linear fluorescence responses observed below pH 4. Finally, both $\mathrm{BF}_{2}$ adducts were shown to act as redox-active ligands when coordinated to nickel(II) ions. In the case of $\mathrm{Ni}(\mathrm{hfac})_{2}$ complexes $\mathbf{1 0 a}$ and $\mathbf{1 0 b}$, the absorption profiles were red-shifted significantly from adducts $\mathbf{8 a}$ and $\mathbf{8 b}$ and ligand-centered reduction events occurred at much less negative potentials. This work, for the first time, has demonstrated that the properties of $\mathrm{BF}_{2}$ formazanate adducts can be modulated using protonation or coordination chemistry, paving the way for the rational design of future generations of functional materials derived from adducts of formazanate ligands.

\section{Acknowledgements}

We would like to thank the University of Western Ontario, the Natural Science and Engineering Research Council (NSERC) of Canada (J. B. G.: DG, 435675, S. M. B. and R. R. M.: CGS D scholarships, and J. V. B.: NSERC USRA scholarship), the Ontario Ministry of Research and Innovation (J. B. G.: ERA, ER14-10-147) and the Canada Foundation for Innovation (J. B. G.: JELF, 33977) for funding this work. Finally we thank Prof. Elizabeth R. Gillies for access to instrumentation in her lab. 


\section{References}

(1) Kamkaew, A.; Lim, S. H.; Lee, H. B.; Kiew, L. V.; Chung, L. Y.; Burgess, K. BODIPY Dyes in Photodynamic Therapy. Chem. Soc. Rev. 2013, 42, 77-88.

(2) Loudet, A.; Burgess, K. BODIPY Dyes and Their Derivatives: Syntheses and Spectroscopic Properties. Chem. Rev. 2007, 107, 4891-4932.

(3) Ulrich, G.; Ziessel, R.; Harriman, A. The Chemistry of Fluorescent Bodipy Dyes: Versatility Unsurpassed. Angew. Chem. Int. Ed. 2008, 47, 1184-1201.

(4) Antina, E. V.; Bumagina, N. A. Tetraaryl-Substituted Aza-BODIPY: Synthesis, Spectral Properties, and Possible Applications. Chem. Heterocycl. Compd. 2017, 53, 39-41.

(5) Tamgho, I.-S.; Hasheminasab, A.; Engle, J. T.; Nemykin, V. N.; Ziegler, C. J. A New Highly Fluorescent and Symmetric Pyrrole-BF ${ }_{2}$ Chromophore: BOPHY. J. Am. Chem. Soc. 2014, 136, $5623-5626$.

(6) Lin, Y.-D.; Ke, B.-Y.; Chang, Y. J.; Chou, P.-T.; Liau, K.-L.; Liu, C.-Y.; Chow, T. J. Pyridomethene- $\mathrm{BF}_{2}$ Complex/Phenothiazine Hybrid Sensitizer with High Molar Extinction Coefficient for Efficient, Sensitized Solar Cells. J. Mater. Chem. A 2015, 3, 16831-16842.

(7) Mirloup, A.; Huaulmé, Q.; Leclerc, N.; Lévêque, P.; Heiser, T.; Retailleau, P.; Ziessel, R. Thienyl-BOPHY Dyes as Promising Templates for Bulk Heterojunction Solar Cells. Chem. Commun. 2015, 51, 14742-14745.

(8) Winsberg, J.; Hagemann, T.; Muench, S.; Friebe, C.; Häupler, B.; Janoschka, T.; Morgenstern, S.; Hager, M. D.; Schubert, U. S. Poly(boron-dipyrromethene) -A Redox-Active Polymer Class for Polymer Redox-Flow Batteries. Chem. Mater. 2016, 28, 3401-3405.

(9) Kowada, T.; Maeda, H.; Kikuchi, K. BODIPY-Based Probes for the Fluorescence Imaging of Biomolecules in Living Cells. Chem. Soc. Rev. 2015, 44, 4953-4972. 
(10) Zhang, X.; Xiao, Y.; Qian, X. A Ratiometric Fluorescent Probe Based on FRET for Imaging $\mathrm{Hg}^{2+}$ Ions in Living Cells. Angew. Chem. Int. Ed. 2008, 47, 8025-8029.

(11) Nepomnyashchii, A. B.; Bröring, M.; Ahrens, J.; Bard, A. J. Synthesis, Photophysical, Electrochemical, and Electrogenerated Chemiluminescence Studies. Multiple Sequential Electron Transfers in BODIPY Monomers, Dinners, Trimers, and Polymer. J. Am. Chem. Soc. 2011, 133, 8633-8645.

(12) Qi, H.; Teesdale, J. J.; Pupillo, R. C.; Rosenthal, J.; Bard, A. J. Synthesis, Electrochemistry, and Electrogenerated Chemiluminescence of Two BODIPY-Appended Bipyridine Homologues. J. Am. Chem. Soc. 2013, 135, 13558-13566.

(13) Yang, Y.; Su, X.; Carroll, C. N.; Aprahamian, I. Aggregation-Induced Emission in BF $2^{-}$ Hydrazone (BODIHY) Complexes. Chem. Sci. 2012, 3, 610-613.

(14) Ashokkumar, P.; Weißhoff, H.; Kraus, W.; Rurack, K. Test-Strip-Based Fluorometric Detection of Fluoride in Aqueous Media with a BODIPY-Linked Hydrogen-Bonding Receptor. Angew. Chem. Int. Ed. 2014, 53, 2225-2229.

(15) Qian, H.; Cousins, M. E.; Horak, E. H.; Wakefield, A.; Liptak, M. D.; Aprahamian, I. Suppression of Kasha's Rule as a Mechanism for Fluorescent Molecular Rotors and Aggregation-Induced Emission. Nat. Chem. 2017, 9, 83-87.

(16) Roubinet, B.; Massif, C.; Moreau, M.; Boschetti, F.; Ulrich, G.; Ziessel, R.; Renard, P.-Y.; Romieu, A. New 3-(Heteroaryl)-2-iminocoumarin-based Borate Complexes: Synthesis, Photophysical Properties, and Rational Functionalization for Biosensing/Biolabeling Applications. Chem. Eur. J. 2015, 21, 14589-14601.

(17) Yoshii, R.; Hirose, A.; Tanaka, K.; Chujo, Y. Functionalization of Boron Diiminates with Unique Optical Properties: Multicolor Tuning of Crystallization-Induced Emission and 
Introduction into the Main Chain of Conjugated Polymers. J. Am. Chem. Soc. 2014, 136, 18131-18139.

(18) Leiner, M. J. P.; Hartmann, P. Theory and Practice in Optical pH Sensing. Sens. Actuators B 1993, 11, 281-289.

(19) Roos, A.; Boron, W. F. Intracellular pH. Physiol. Rev. 1981, 61, 296-434.

(20) Gottlieb, R. A.; Nordberg, J.; Skowronski, E.; Babior, B. M. Apoptosis Induced in Jurkat Cells by Several Agents is Preceded by Intracellular Acidification. Proc. Natl. Acad. Sci. USA 1996, 93, 654-658.

(21) Strobl, M.; Rappitsch, T.; Borisov, S. M.; Mayr, T.; Klimant, I. NIR-emitting Aza-BODIPY Dyes - New Building Blocks for Broad-Range Optical pH Sensors. Analyst 2015, 140, 7150-7153.

(22) Yin, Z.; Tam, A. Y.-Y.; Wong, K. M.-C.; Tao, C.-H.; Li, B.; Poon, C.-T.; Wu, L.; Yam, V. W.-W. Functionalized BODIPY with Various Sensory Units - A Versatile Colorimetric and Luminescent Probe for $\mathrm{pH}$ and Ions. Dalton Trans. 2012, 41, 11340-11350.

(23) Moßhammer, M.; Strobl, M.; Kühl, M.; Klimant, I.; Borisov, S. M.; Koren, K. Design and Application of an Optical Sensor for Simultaneous Imaging of $\mathrm{pH}$ and Dissolved $\mathrm{O}_{2}$ with Low Cross-Talk. ACS Sens. 2016, 1, 681-687.

(24) Strobl, M.; Mayr, T.; Klimant, I.; Borisov, S. M. Photostable Upconverting and Downconverting pH Sensors Based on Combination of a Colorimetric NIR Indicator and Stable Inorganic Phosphors as Secondary Emitters. Sens. Actuators, B 2017, 245, 972-979.

(25) Han, F.; Xu, Y.; Jiang, D.; Qin, Y.; Chen, H. A BODIPY-Derived Fluorescent Probe for Cellular pH Measurements. Anal. Biochem. 2013, 435, 106-113. 
(26) Rao, Y.-L.; Wang, S. Impact of Cyclometalation and $\pi$-Conjugation on Photoisomerization of an N,C-Chelate Organoboron Compound. Organometallics 2011, 30, 4453-4458.

(27) Geist, F.; Jackel, A.; Irmler, P.; Linseis, M.; Malzkuhn, S.; Kuss-Petermann, M.; Wenger, O. S.; Winter, R. F. Directing Energy Transfer in Panchromatic Platinum Complexes for Dual Vis-Near-IR or Dual Visible Emission from o-Bonded BODIPY Dyes. Inorg. Chem. 2017, 56, 914-930.

(28) Hudson, Z. M.; Helander, M. G.; Lu, Z.-H.; Wang, S. Highly Efficient Orange Electrophosphorescence from a Trifunctional Organoboron-Pt(II) Complex. Chem. Commun. 2011, 47, 755-757.

(29) Wu, W.; Zhao, J.; Guo, H.; Sun, J.; Ji, S.; Wang, Z. Long-Lived Room-Temperature NearIR Phosphorescence of BODIPY in a Visible-Light-Harvesting $\mathrm{N}^{\wedge} \mathrm{C}^{\wedge} \mathrm{N}$ PtII-Acetylide Complex with a Directly Metalated BODIPY Chromophore. Chem. Eur. J. 2012, 18, 1961-1968.

(30) Chu, G. M.; Guerrero-Martínez, A.; Ramírez de Arellano, C.; Fernández, I.; Sierra, M. A. Remote Control by $\pi$-Conjugation of the Emissive Properties of Fischer Carbene-BODIPY Dyads. Inorg. Chem. 2016, 55, 2737-2747.

(31) Galletta, M.; Puntoriero, F.; Campagna, S.; Chiorboli, C.; Quesada, M.; Goeb, S.; Ziessel, R. Absorption Spectra, Photophysical Properties, and Redox Behavior of Ruthenium(II) Polypyridine Complexes Containing Accessory Dipyrromethene- $\mathrm{BF}_{2}$ Chromophores. J. Phys. Chem. A 2006, 110, 4348-4358.

(32) Jeong, S. Y.; Lalancette, R. A.; Lin, H.; Lupinska, P.; Shipman, P. O.; John, A.; Sheridan, J. B.; Jäkle, F. "Third-Generation"-Type Functional Tris(2-pyridyl)borate Ligands and Their Transition-Metal Complexes. Inorg. Chem. 2016, 55, 3605-3615. 
(33) Nawn, G.; McDonald, R.; Hicks, R. G. Synthesis and Characterization of Heterobimetallic (Pd/B) Nindigo Complexes and Comparisons to Their Homobimetallic $\left(\mathrm{Pd}_{2}, \mathrm{~B}_{2}\right)$ Analogues. Inorg. Chem. 2013, 52, 10912-10919.

(34) Shin, I.-S.; Bae, S. W.; Kim, H.; Hong, J.-I. Electrogenerated Chemiluminescent Anion Sensing: Selective Recognition and Sensing of Pyrophosphate. Anal. Chem. 2010, 82, 8259-8265.

(35) Aprahamian, I. Hydrazone Switches and Things in Between. Chem. Commun. 2017, 53, $6674-6684$.

(36) Yang, Y.; Hughes, R. P.; Aprahamian, I. Visible Light Switching of a BF $2-C$ Coordinated Azo Compound. J. Am. Chem. Soc. 2012, 134, 15221-15224.

(37) Barbon, S. M.; Price, J. T.; Reinkeluers, P. A.; Gilroy, J. B. Substituent-Dependent Optical and Electrochemical Properties of Triarylformazanate Boron Difluoride Complexes. Inorg. Chem. 2014, 53, 10585-10593.

(38) Barbon, S. M.; Reinkeluers, P. A.; Price, J. T.; Staroverov, V. N.; Gilroy, J. B. Structurally Tunable 3-Cyanoformazanate Boron Difluoride Dyes. Chem. Eur. J. 2014, 20, 11340-11344.

(39) Barbon, S. M.; Staroverov, V. N.; Gilroy, J. B. Effect of Extended $\pi$ Conjugation on the Spectroscopic and Electrochemical Properties of Boron Difluoride Formazanate Complexes. J. Org. Chem. 2015, 80, 5226-5235.

(40) Chang, M.-C.; Chantzis, A.; Jacquemin, D.; Otten, E. Boron Difluorides with Formazanate Ligands: Redox-Switchable Fluorescent Dyes with Large Stokes Shifts. Dalton Trans. 2016, 45, 9477-9484. 
(41) Chang, M.-C.; Otten, E. Synthesis and Ligand-Based Reduction Chemistry of Boron Difluoride Complexes with Redox-Active Formazanate Ligands. Chem. Commun. 2014, 50, $7431-7433$.

(42) Maar, R. R.; Barbon, S. M.; Sharma, N.; Groom, H.; Luyt, L. G.; Gilroy, J. B. Evaluation of Anisole-Substituted Boron Difluoride Formazanate Complexes for Fluorescence Cell Imaging. Chem. Eur. J. 2015, 21, 15589-15599.

(43) Barbon, S. M.; Novoa, S.; Bender, D.; Groom, H.; Luyt, L. G.; Gilroy, J. B. CopperAssisted Azide-Alkyne Cycloaddition Chemistry as a Tool for the Production of Emissive Boron Difluoride 3-Cyanoformazanates. Org. Chem. Front. 2017, 4, 178-190.

(44) Hesari, M.; Barbon, S. M.; Staroverov, V. N.; Ding, Z.; Gilroy, J. B. Efficient Electrochemiluminescence of a Readily Accessible Boron Difluoride Formazanate Dye. Chem. Commun. 2015, 51, 3766-3769.

(45) Chang, M.-C.; Otten, E. Reduction of (Formazanate)boron Difluoride Provides Evidence for an N-Heterocyclic B(I) Carbenoid Intermediate. Inorg. Chem. 2015, 54, 8656-8664.

(46) Barbon, S. M.; Staroverov, V. N.; Gilroy, J. B. Structurally Diverse Boron-Nitrogen Heterocycles from an $\mathrm{N}_{2} \mathrm{O}_{2}{ }^{3-}$ Formazanate Ligand. Angew. Chem. Int. Ed. 2017, 56, 8173-8177.

(47) Maar, R. R.; Gilroy, J. B. Aggregation-Induced Emission Enhancement in Boron Difluoride Complexes of 3-Cyanoformazanates. J. Mater. Chem. C 2016, 4, 6478-6482.

(48) Barbon, S. M.; Gilroy, J. B. Boron Difluoride Formazanate Copolymers with 9,9-di-nhexylfluorene Prepared by Copper-Catalyzed Alkyne-Azide Cycloaddition Chemistry. Polym. Chem. 2016, 7, 3589-3598. 
(49) Novoa, S.; Paquette, J. A.; Barbon, S. M.; Maar, R. R.; Gilroy, J. B. Side-Chain Boron Difluoride Formazanate Polymers via Ring-Opening Metathesis Polymerization. J. Mater. Chem. C 2016, 4, 3987-3994.

(50) Fery-Forgues, S.; Lavabre, D. Are Fluorescence Quantum Yields so Tricky to Measure? A Demonstration Using Familiar Stationery Products. J. Chem. Educ. 1999, 76, 1260-1264.

(51) Suzuki, K.; Kobayashi, A.; Kaneko, S.; Takehira, K.; Yoshihara, T.; Ishida, H.; Shiina, Y.; Oishi, S.; Tobita, S. Reevaluation of Absolute Luminescence Quantum Yields of Standard Solutions Using a Spectrometer with an Integrating Sphere and a Back-Thinned CCD Detector. Phys. Chem. Chem. Phys. 2009, 11, 9850-9860.

(52) Bruker-AXS, SAINT version 2013.2018, 2013, Bruker-AXS, Madison, WI 53711, USA.

(53) Bruker-Nonius, SADABS version 2012.1, 2012, Bruker-AXS, Madison, WI 53711, USA.

(54) Bruker-Nonius, TWINABS version 2012.1, 2012, Bruker-AXS, Madison, WI 53711, USA.

(55) Sheldrick, G. M. SHELXT - Integrated Space-Group and Crystal-Structure Determination. Acta Cryst. 2015, A71, 3-8.

(56) Spek, A. L. PLATON SQUEEZE: a Tool for the Calculation of the Disordered Solvent Contribution to the Calculated Structure Factors. Acta Cryst. 2015, C71, 9-19.

(57) Nineham, A. W. The Chemistry of Formazans and Tetrazolium Salts. Chem. Rev. 1955, 55, 355-483.

(58) Travieso-Puente, R.; Budzak, S.; Chen, J.; Stacko, P.; Jastrzebski, J. T. B. H.; Jacquemin, D.; Otten, E. Arylazoindazole Photoswitches: Facile Synthesis and Functionalization via SNAr Substitution. J. Am. Chem. Soc. 2017, 139, 3328-3331.

(59) CRC Handbook of Chemistry and Physics; CRC Press: Boca Raton, FL, 2012. 
(60) Sadler, J. L.; Bard, A. J. Electrochemical Reduction of Aromatic Azo Compounds. J. Am. Chem. Soc. 1968, 90, 1979-1989.

(61) Adugna, S.; Revunova, K.; Djukic, B.; Gorelsky, S. I.; Jenkins, H. A.; Lemaire, M. T. Persistent Metal Bis(Hexafluoroacetylacetonato) Complexes Featuring a 2,2'-Bipyridine Substituted Triarylamminium Radical Cation. Inorg. Chem. 2010, 49, 10183-10190.

\section{For Table of Contents Only}

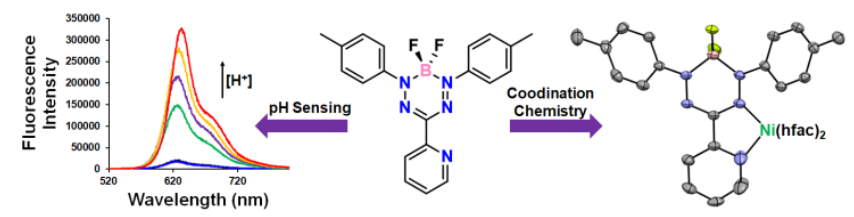

The synthesis and characterization of a flexidentate pyridine-substituted formazanate ligand and its boron difluoride adducts, formed via two different coordination modes of the title ligand, are described. Protonation of the pyridine substituent and coordination to nickel(II) ions altered the physical and electronic properties of the $\mathrm{BF}_{2}$ formazanate adducts, demonstrating that their properties can be readily modulated by exploiting the chemistry of the pyridine substituent. 